\title{
REGULATING CROWDFUNDING IN THE EU -SAME RULES, SAME RESULTS? CASE STUDY OF CROATIA ${ }^{1}$
}

\author{
Ivana BAJAKIĆ \\ Associate professor, Faculty of Law, University of Zagreb, Croatia \\ E-mail: ivana.bajakic@pravo.hr
}

Marta BOŽINA BEROŠ

Associate professor, Faculty of economics and tourism "Dr. Mijo Mirković"

Juraj Dobrila University, Croatia

E-mail: mbozina@unipu.hr

\section{Ana GRDOVIĆ GNIP}

Assistant Professor, Faculty of mathematics, natural sciences and information technologies

University of Primorska, Slovenia

E-mail: ana.grdovic@famnit.upr.si

\begin{abstract}
Fintech embodies technological innovations in financial services. The scholarship in this area is fast-growing and correlates with a disruptive potential Fintech has for the financial ecosystem. European regulation is also keeping up with this phenomenon. A case in point is the recently adopted EU crowdfunding regulation which is part of the EU's FinTech Action Plan and Capital Markets Union agenda. Its general goal is to promote financial development of European financial systems by enhancing alternative finance sources to bank lending and cross-border investments. On the one hand, the EU crowdfunding regulation aims to enhance scalability for crowdfunding platforms service providers across the European single market through a single EU crowdfunding licence. On the other hand, regulation intends to provide a high level of investor protection across Europe through a unified set of rules. The purpose of this paper is twofold. First, to outline the European regulatory and policy agenda in addressing disruptive impacts of FinTech and crowdfunding
\end{abstract}

${ }^{1}$ Ivana Bajakić acknowledges the support of the Erasmus+ Jean Monnet Module 599866-EPP-1-2018- 1-HR- EPPJMO-MODULE (EU Financial Markets and Regulation); Ana Grdović Gnip acknowledges the support of the Erasmus+ Jean Monnet Module 600616-EPP-1-2018-1-SI- EPPJMO-MODULE (EU Economic Trends). 
on capital markets. Second, to open and encourage timely policy discussions on how these regulatory trends could unfold in Croatia and the South Eastern European (SEE) region, characterised as more traditional financial markets services and developing capital markets in comparison to other member states. Thus, the methodology combines secondary data analysis with a case study. Our findings suggest that the likely effects of the EU crowdfunding regulation reflect in improved legal certainty for investors and increased potential for financial development in alternative financing, although there is significant space for improvement of the Croatian financial ecosystem.

Key words: crowdfunding, FinTech, European financial regulation, Croatia, capital markets

\section{INTRODUCTION}

Up to the present, financial systems in the $21^{\text {st }}$ century have been driven by two extraordinary events, the global financial crisis of 2007-08 (GFC) and pioneering technological innovations in finance (FinTech). The global financial crisis reshaped global financial regulation and governance. The first wave of the U.S. financial crisis spilled over to a global interbank credit crisis and affected western European banks with exposure to toxic assets, leading to several bouts of recapitalizations. The second wave unveiled the fragility of EU member states' financial systems causing the European debt crisis of 2010-11 and leading to immense financial recuperation programmes for several countries. Both financial crises provoked massive reforms of the European financial system, initiating ambitious policy projects such as the Banking Union and Capital Markets Union, in which the former initiative redesigned the regulatory, supervisory and recovery models of the banking sector centralizing it on the EU level. The latter aimed to complement bank-based financing with more active capital markets across the EU and seizing the potential that financial innovation, chief among them FinTech, presented for financial intermediation.

FinTech represents technological innovations in the financial sector, with a farreaching changes of the financial ecosystem. FinTech has been commonly defined as "technology-enabled innovation in financial services that could result in new business models, applications, processes or products with an associated material effect on the provision of financial services" (Financial Stability Board, 2019, p. 2, n. 1). The financial industry is the most propulsive sector for innovative technologies, with respect to the magnitude of investments in the field (European Commission, 2018a, p. 1). Although Fintech is quite a new term, covering different financial zones and market players, its modus is 
well-established. In fact, technology has been known to support financial services for at least the last two centuries, e.g. money transfers using the telegraph in the $19^{\text {th }}$ century, card readers and ATMs during the $20^{\text {th }}$ century (Arner, Barberis and Buckley, 2016, p. 1274-1283). FinTech is currently a relatively general concept, since it is not quite clear and precise what the market structure for FinTech is, who the Fintech players are between the incumbents such as banks and insurers, Big Data companies and start-ups, etc. (Schueffel, 2016).

With regard to FinTech's regulation, there is a growing body of literature on the principles and methods for its regulation (Amstad, 2019; Ehrentraud, et. al., 2020; Restoy, 2021) although it is yet another broad-spectrum area. First of all, technology itself is a neutral category, it does not imply financial fraud or systemic risk creation. Human behaviour while using the technology will be in charge of that. Generally, there are some areas like artificial intelligence (AI) and distributed ledger technologies (DLTs) that will most likely require certain future rule parameters (Digital Finance Strategy for the EU, 2020). These areas are not exclusively in the financial domain, rather a part of a broader range, therefore requiring a multidisciplinary and cross-jurisdictional approach coordinated at the EU level, e.g. Digital Single Market. Other areas, such as financial stability, financial integrity, consumer protection, competition policy and systemic risk have already been addressed by a plethora of EU financial regulation. Hence, there are considerations on how to navigate the level playing field in the financial sector with regard to BigTech's double role in the financial eco-system. First, as third-party providers of the financial infrastructure for incumbents (e.g. service or applications for banks) and second, as competitors, by simultaneously entering the market as providers of certain financial services (e.g. payments, lending) with immense disruption potential through a gigantic customer database and processing capabilities (Restoy, 2021).

Moreover, competitiveness of the EU in the FinTech area is significantly lagging behind the U.S. and China. Brexit exacerbated Europe's score since the U.K. presents an extraordinary market base for successful FinTechs. Additionally, the UK is considered a global innovator in terms of regulatory approach to FinTechs through innovation facilitators, i.e. innovation hubs and regulatory sandboxes (Cambridge Centre for Alternative Finance, 2018). Therefore, the EU selected a more cautious approach to regulating FinTech with an ambition not to hinder scalability prospects for innovative business models within the Single Market (European Commission, 2018a).

To this end, the EU Crowdfunding Regulation 2020/1503 (thereafter: crowdfunding regulation) aims to enhance scalability for crowdfunding platforms service providers across the European single market by means of the EU crowdfunding licence which facilitates operations across EU member states' national markets. On the one hand, regulation intends to provide legal certainty for investors across Europe through a single set of rules. On the other hand, crowdfunding platform providers should benefit from the ability to carry 
out services under the same conditions, regardless where they are primarily established in the EU, therefore reducing their operational and compliance costs while expanding their businesses across the EU (European Commission, 2018b).

Given the excessive complexity that FinTech generates in an already turbulent post crisis financial ecosystem, it is beyond the scope of this paper to envisage and scrutinize the complete inventory of potential impacts and probabilities that crowdfunding regulation could exert on EU member states' capital markets. Instead, the purpose and contribution of this paper are situated in a conceptual analysis. In a sense this paper presents a scoping research in the subject, with a twofold objective. First, to outline the European regulatory and policy agenda in addressing disruptive impacts of FinTech and crowdfunding on capital markets. Second, to contribute to wider policy discussions on how these regulatory trends could unfold in Croatia and the South Eastern European (SEE) region, characterised as more traditional financial markets, services and developing capital markets. In order to achieve these goals, our methodology combines qualitative, secondary data analysis, as well as statistical data sources substantiated with a case study.

The paper proceeds as follows: chapter two provides an overview of building blocks and policy developments of the Capital Markets Union. Chapter three outlines objectives for European crowdfunding regulation and its impact assessment for the European capital markets. Chapter four looks deeper into disruptive impacts of Fintech on capital markets, with special emphasis on the implications of crowdfunding on capital markets. Chapter five discusses possible sequels of the crowdfunding regulation on the Croatian capital markets. Chapter six concludes, proposing some policy recommendations for Croatia, as well as the SEE region, from the perspective of this recent EU member state catching up on financial developments.

\section{BUILDING THE CAPITAL MARKETS UNION}

For decades, European financial systems have been operating largely as bankoriented systems, with limited convergence to market-based banking in western European economies (Hardie, Howarth, Maxfield and Verdun, 2013). Both economic and legal national systems of the EU member states have been divided through the lines of Anglo-Saxon and Continental systems, creating barriers for legal harmonisation and the creation of a genuine European financial market. Until the 1990s, the EU applied a minimum harmonisation approach, introducing principles of mutual recognition, minimum technical standards and home country control (Ferran, 2004: 1-7; Moloney 2008: 11-16).

Financial globalization and integration pushed forward for the creation of the Economic and Monetary Union (EMU) and the single currency at the beginning of the 1990s. As part of the EMU's programme, the Lisbon strategy for the 
Regulating crowdfunding in the EU- same rules, same results? ...

2000-2010 period stimulated a new policy agenda for economic growth and social inclusion. The result was a large regulatory overhaul in the financial sector, the Financial Services Action Plan (FSAP), implemented between 1999 and 2005 with a goal to build a new regulatory architecture that would allow safer and more efficient cross border financial transactions and other operations by financial institutions (European Commission, 1999, 2005). FSAP's flagship MiFID directive unlocked competition of the European capital markets.

The ambitious policy intentions of regulatory harmonisation were disrupted by the GFC, during which financial institutions and investors changed course back to their home markets (European Central Bank, 2009; European Commission, 2009, 2015a). The European Commission's Green Paper analysis reports that the European capital markets remain fragmented and underdeveloped. "Compared with other jurisdictions, capital market based financing in Europe is relatively underdeveloped. Our equity, debt and other markets play a smaller role in financing growth and European businesses remain heavily reliant on banks, making our economies vulnerable to a tightening of bank lending. There is also insufficient investor confidence, and European savings are not always being put to the most productive use. European investment levels are well below their historical norm and European capital markets are less competitive at the global level" (European Commission, 2015a, p. 4).

In the aftermath of the GFC and European debt crisis of 2010-11, a new policy agenda generated the creation of the Banking Union and Capital Markets Union (European Commission, 2015b). While the Banking Union represents significant financial integration, through centralized regulation, supervision and resolution for the banking sector, the Capital Markets Union has been more of a complementary strategy for promoting alternative sources of financing (Howarth and Quaglia, 2016, p. 212-213).

The New Capital Markets Union Action Plan accentuates the need to generate additional sources of funding, especially to small and medium-sized businesses. Recent policy emphasis on sustainable finance (Greener and Cleaner Economy, European Commission, 2018c) have been reaffirmed as a set of environmental, social and governance (ESG) goals for circumventing the K-shape post-corona recovery trail, of "rich getting richer and poor getting poorer". The European forward-thinking strategy of green and digital markets conveying to a more inclusive and resilient economy is certainly a cutting-edge policy, even though implementation might be tentative (Macchiavello and Siri, 2020).

\section{THE TWOFOLD RATIONALE OF THE EU CROWDFUNDING REGULATION}

The EU Crowdfunding Regulation was proposed in 2018 as a part of the FinTech Action Plan, the European Commission's strategy for enhancing the opportunities of financial markets through utilising cutting-edge technologies, 
such as blockchain and artificial intelligence. (European Commission, 2018a), following the Mid-Term Review of the Capital Markets Union Action Plan (European Commission, 2017).

Crowdfunding services are defined in art. 2 of the Crowdfunding regulation as: "the matching of business funding interests of investors and project owners through the use of a crowdfunding platform and which consists of any of the following activities: (i) the facilitation of granting of loans; (ii) the placing without a firm commitment basis, as referred to in point (7) of Section A of Annex I to Directive 2014/65/EU, of transferable securities and admitted instruments for crowdfunding purposes issued by project owners or a special purpose vehicle, and the reception and transmission of client orders, as referred to in point (1) of that Section, in relation to those transferable securities and admitted instruments for crowdfunding purposes."

The regulatory rationale concerning crowdfunding was twofold. First, to enable fast growing start-ups to gain better access to financing of their business projects, especially at an early transformational stage in which scaling is crucial for their business model. Crowdfunding represents an innovative technology enabled platform that allows for more efficient and easier matchmaking for investors and businesses. Therefore, it has been identified as a useful mechanism for deepening the EU's Capital Markets Union. Second, it enhances investor protection and increases cross-border investment activities. Arguably, a troublesome lack of trust arising from information asymmetries concerning project riskiness and crowdfunding platforms' operational risks has been identified. Subsequently, cross-border funding activity within the EU amounted to $0,73 \%$ of the total raised between 2013 and 2014 (European Commission, 2018b, p. 18).

At the same time, crowdfunding represents the most important alternative finance source to bank lending for entrepreneurs. Indeed, crowdfunding is designed as a tool to provide investment opportunities to a large pool of primarily natural persons who place relatively modest investment amounts via a publicly available, internet-based platform. While the UK has the biggest market share in alternative finance, the crowdfunding market has been developing rapidly in other EU countries, especially France, Germany, the Netherlands, Finland and Spain. While there have been positive trends at the European crowdfunding market with regard to intensification of institutional investors and general public financier's interest, the markets remained prevailingly domestically oriented with limited cross-border activities concentrated in a few large countries (Ibid., p. 16-28). European crowdfunding platforms account for approximately $34 \%$ of all alternative finance raised in Europe (excluding the UK). In terms of total size, they amounted to 2.624 million USD raised for businesses over crowdfunding platforms in 2018, with an annual growth of $140 \%$. The business funding model is predominantly a debt-based model, accounting for $81 \%$ vs. the equity-based model, which 
accounts for $17 \%$ of business funding (Cambridge Centre for Alternative Finance, 2020, p. 83-86). The data suggests that there is also a "bank-based financing / debt based mentality" by European investors, being more risk averse, i.e. avoiding acquiring stakes in businesses through equity crowdfunding and losing all their investment in case business fails vs. riskier model of investment with higher returns potential.

Crowdfunding services have been subject to a diversified set of rules and procedures in different member states, e.g. some national regimes required licencing and operation under the MiFID II regime, while others had no special requirements in place. This variety of fragmented and intermittently conflicting national regulatory frameworks increased operational and compliance costs of crowdfunding service providers impending scaling up of crowdfunding platforms, while obstructing cross-border activities and fragmenting the European capital markets (European Commission, 2018b, Crowdfunding Regulation, preamble, point 6).

The EU crowdfunding regulation $2020 / 1503$ entered into force on $10^{\text {th }}$ November 2020, and will become applicable on $10^{\text {th }}$ November 2021 with an additional transition period of 12 to maximum 24 months for crowdfunding service providers to obtain authorisation for providing lending-based and investment-based (equity) crowdfunding services (art 48). Crowdfunding service providers are required to operate as neutral intermediaries (art. 8), handle client complaints (art. 7) and appoint effective and prudent management to undertake credit risk assessments of the crowdfunding projects, including a minimum level of due diligence in respect of project owners (art. 4-5). They are subject to various prudential requirements (art. 11).

To ensure investor protection, the maximum amount that can be raised in a single crowdfunding project is 5 million EUR (art. 49). Regulation distinguishes between sophisticated and non-sophisticated investors through an entry knowledge test and simulation of the ability to bear loss (art. 21), with additional safeguard clauses, such as explicit risk warnings and a precontractual reflection period of four days during which a prospective nonsophisticated investor can revoke an offer to invest (art. 22). Potential investors must receive a maximum 6-page key investment information sheet, containing specific features of the project and a potential financial risk warning, drawn up by the project owner and verified by the crowdfunding service providers (art. 23).

Crowdfunding platform service providers are prohibited from taking deposits (art. 10) and are not allowed to operate as trading venues. Instead, they are allowed to operate a bulletin board, which permits their clients to advertise interest in buying and selling loans, transferable securities or admitted instruments for crowdfunding purposes that were originally offered on their crowdfunding platforms (art. 25). 


\section{THE DISRUPTIVE IMPACT OF FINTECH AND CROWDFUNDING ON CAPITAL MARKETS}

Schumpeter $(1942$, p. 83) developed a concept of creative destruction to describe the innovative force of capitalism which "incessantly revolutionizes the economic structure from within, incessantly destroying the old one, incessantly creating a new one". Although innovations can be revolutionary, they might not have the disruptive effect to reset the market with new products, institutions and value chains, e.g. innovation of car vs. mass-production of cars. Disruptive innovations tend to be cultivated in entrepreneurial start-ups rather than incumbent companies (Christensen et. al., 2015; Bower et. al., 1995). Although there is a public perception of FinTechs as financial ecosystem gamechangers, they haven not yet reshaped the financial system: "FinTechs have materially changed the basis of competition in financial service, but have not yet materially changed the competitive landscape ... Although Fintech failed to disrupt the competitive landscape, they have laid the foundation for future disruption." (World Economic Forum \& Deloitte, 2017, p. 12-13).

Financial stakeholders have identified the utmost disruptive forces that will change the financial industry. Distributed ledger technology (DLT), better known as blockchain, has the capacity to alter almost every aspect of financial services including payment, clearing, and settlement, etc. by reducing the complexity of transactions and increasing the speed, security and transparency of operations (Bank for International Settlements, 2017, European Securities and Markets Authority, 2017). Data analysis and artificial intelligence (AI) will personalize financial services. Along with automation and robotics, it will offer more choices leading to better and cheaper financial products (Financial Stability Board, 2017). Cloud services bring cost advantages, flexibility and efficiency with options to run different financial services in the cloud (McKinsey \& Company, 2018). All of these innovations have great potential to advance as well as undermine financial stability (Financial Stability Board, 2019, 2017).

With regard to financial market players, these are tipically divided into three groups: (i) the incumbents (banks, stock-exchanges, etc.), (ii) start-ups and, (iii) tech giants (BigTech). Market research shows that FinTech start-ups are more oriented towards collaboration with incumbents, rather than competing with them. While the starting strategy was probably to take-over the market, newcomers experienced difficulties in building a customer base and scaling business, therefore they oriented more on business-to-business solutions (B2B). By partnering up with these start-ups, traditional financial institutions are acquiring new technology solutions as a way to increase productivity and revenues. On the other side, the impact of large technological giants such as Microsoft, Amazon, Alibaba, Apple or Google on the future of financial markets has yet to unfold. They have unprecedented potential in data 
ownership, cloud-based infrastructure, data analytics and artificial intelligence. In other words, they have great potential to disrupt the financial ecosystem on a previously unimaginable scale. Market analysts forecast that ownership and control of data will determine new market champions capturing the largest profit pools with a data intensive and platform-based business model (McKinsey \& Company, 2018; World Economic Forum \& Deloitte, 2017, 2015; Financial Stability Board, 2019).

There are around 700 FinTechs operating on capital markets worldwide. It is the fastest growing FinTech sector, expanding at the rate of $277 \%$ since 2010. Market analysis shows that major disruptive impacts are in the areas of access to capital and post-trade services powered by blockchain technologies and automation (McKinsey \& Company, 2018, p. 7-9). Start-ups are mostly collaborating with incumbents, with an exemption of access to capital, zone of disintermediation, where start-ups have created new platforms that provide a direct link between investors and companies and represent a worrying challenge to traditional intermediaries such as banks, brokers, clearing and settlement and depository registries.

Crowdfunding has been growing rapidly over the last decade. This is an innovative platform for raising smaller amounts of capital globally for different types of projects. Crowdfunding service providers rely on blockchain technologies, which allows them consolidation of the value chain. New technology allows for more effective linking of supply and demand around the common digital platform through disintermediating some traditional services, e.g. stock exchanges, clearance and settlement. The World Economic Forums' study (2017, p. 147-167) on equity crowdfunding identified several important trends. There is accelerating demand from both investors and start-ups. This brings uncertainty for the future concerning limited scalability and change in demand driven by current euphoric investors. There are also concerns regarding valuations on crowdfunding platforms. This directs attention to issues such as digital financial literacy, consequently creating a new demand for FinTech commercial due diligence through AI and further promotion of the investor-led model and start-up exchange venues. Finally, the market research points to the quality of regulation, i.e. balance between support for growth through alternative access to capital combined with investor protection, being the key formula to crowdfunding success.

Crowdfunding has another downside because of liquidity, i.e. the platforms are designed as a capital raising platform for smaller scale projects, like start-ups and SMEs. They are not allowed to have a trading system (art. 25, Crowdfunding Regulation) because that would make them a stock exchange, a regulated entity under MiFID rules. Instead, there was a compromise solution installed on the EU level to promote alternative access to capital without suffocating it with disproportional regulatory measures. Therefore, some platforms offer placing buyers and sellers orders in a vintage, $20^{\text {th }}$ century 
auction manner, which is a regulatory bypass solution for the time being. During past years, crowdfunding platforms have been teaming up with national stock exchanges, e.g. SyndicateRoom with London Stock Exchange, Funderbeam with Zagreb Stock Exchange, gaining access to a wider financial ecosystem (Business Insider, 2016; Zagreb Stock Exchange 2016).

Among all of these incumbents, stock exchanges appear to be the most prepared to embrace change. This could be explained through their experience in surviving the first round of regulatory disruption, when MiFID introduced competition between exchanges and alternative trading venues across European capital markets. MiFID resulted in increased market competition and fragmentation, growth of dark pools and broker-dealer crossing systems. First, national stock exchanges lost their advantage over the most liquid domestic shares. Second, high investment in I T through software trading and platforms, along with transfers of liquidity (trading of liquid shares) forced national stock exchanges to join new pan-European trading consolidators: NYSE Euronext, LSE Group, Deutsche Börse and Nasdaq OMX (CEPS, 2011; Europe Economics, 2011). Nevertheless, these financial incumbents have a lot to offer as potential partners to new platforms, a capital and customer base along with immense expertise in dealing with regulators and regulatory changes.

\section{ENVISAGING THE IMPACT OF EU CROWDFUNDING REGULATION ON THE CROATIAN CAPITAL MARKET}

Although absolute figures confirm that in terms of total volume, the global alternative finance leaders are China and the US, in per capita terms, countries with relatively high volumes are predominantly European, the top two being Latvia and Estonia (Cambridge Centre for Alternative Finance, 2020, p. 24). These are small EU member states, similar to Croatia, yet strongly oriented to digitalization, which then translates into the digitization of finance. The SEE region has a joint alternative finance volume of 188 million USD, growing more than $250 \%$ annually (Ibid., p. 78). The business funding model is even more debt-based, amounting to $96 \%$, vs. EU average of $81 \%$, with less than $1 \%$ being equity based, vs. EU average of $17 \%$, which again emphasises the strong dominance of bank-based financing mentality.

Interestingly, the Croatian financial system has a substantive financing pool, i.e. individual savings accounts amount to more than 26 billion EUR (Croatian National Bank, 2021). Additionally, more then $50 \%$ of Croatian citizens have a personal pension account and more than one million persons, almost $10 \%$ of population, have a registered securities account with the Central Depository and Clearing Company (2021). There is therefore a noteworthy pool of potential Croatian investors. For example, historically, during the well marketed Croatian Telecom's IPO in 2007 more then 350.000 natural persons were investors. The data clearly suggests there is a potential demand to invest in good business projects. 
It is precisely the perspective of more general investors, i.e. natural persons, that were at the primary centre of EU regulators' attention in developing a crowdfunding regulation that will provide greater legal certainty for investors. It is therefore a general benefit which should also have a positive effect on Croatian investors. The undermining factor could be a comparatively low level of general financial literacy in Croatia (Batsaikhan, Demertzis, 2018; Pintarić, 2020) which could be further downgraded when examining digital financial literacy. This could be particularly challenging when addressing the nonsophisticated investors and their understanding of the risk involved. Consequently, it could remain a barrier for engaging in the FinTech products and services, with Croatians leaning more towards traditional financial activities such as investing in real-estate or bank savings. Therefore, safeguard clauses provided in the EU crowdfunding regulation, e.g. risks warnings in the key information sheet and obligatory information that crowdfunding investment does not provide insurance schemes similar to deposit insurance arrangements should help investors make more informed decisions.

Still, we have to keep account of the perception of regulatory adequacy in the pre-crowdfunding regulatory framework, which was unfavourable in the SEE region (Cambridge Centre for Alternative Finance, 2020, p. 105-106). The Croatian financial market is predominantly a bank-based system. The regulatory and supervisory framework was drastically altered during the last decade, due to Croatian membership in the EU. The EU regulation in this area is however, largely unfit for the purpose. First, European policy initiatives for promoting a more market-based banking system, e.g. covered bonds initiative, are inadequate due to underdevelopment of the Croatian financial markets (Bajakić, 2019). Second, MiFID's I \& II operational and compliance requirements (along with the GFC) contributed to further decrease and consolidation of investment firms in the Croatian capital markets troubled with modest volume and liquidity (Bajakić, 2020, p. 925-930).

In order to support Fintech development of capital markets, Croatian Financial Services Supervisory Agency, HANFA, in May of 2019, established an innovation facilitator in the form of an innovation hub to support and enhance FinTech firms in Croatia (Ibid.). HANFA (2020) has also adopted Guidelines for pension funds' investments in SMEs through crowdfunding platforms to unleash the credit potential and direct it towards start-ups and SMEs development. Additionally, HANFA's new capital markets legislation allows for easier access to capital markets for issuers issuing securities below 8 million EUR (HANFA, 2021).

In the SEE markets, foreign platforms surpass local platforms, having typically one platform dominating the entire alternative finance volume, e.g. P2P (peerto-peer) consumer lending in Bulgaria, or invoice trading in Slovenia (Ziegler, T. et al., 2019, p. 134-135). The Zagreb Stock Exchange (ZSE) displayed great 
adaptability to both regulatory and market changes and challenges. ZSE collaborated with FinTech challengers, taking a 20\% equity share in Funderbeam SEE, an Estonian equity-based crowdfunding platform service provider, in addition to Progress, their own platform for SMEs financing. Theoretically, the new crowdfunding regulation could become an entry barrier for establishment of Croatian crowdfunding service providers due to operational and prudential requirements that increase operational costs. However, with the currently operative ZSE's platform and Funderbeam, there is most likely no demand for such an initiative. Therefore, Croatia primarly needs to constructively focus on policies for developing competitiveness of entrepreneurship and financial markets.

\section{CONCLUDING REMARKS AND SOME POLICY RECOMMENDATIONS}

Good financial regulation rests on two pillars: appropriate rules and their consistent implementation in practice. Generally speaking, excessive regulation can undermine market efficiency resulting in regulatory arbitrage and investor flight to other financial markets. Too little regulation enhances motivation for moral hazard and fraud. Too much regulation stifles innovation and opportunities for better capital allocation and risk mitigation. In this perspective, the regulation of FinTech is particularly challenging because it demands a delicate balance be struck between the forward-thinking consumer and investor protection rules with enough lenience to generate financial innovations that are conducive to economic growth and development. Although the jury is still out on the impacts of the recently introduced crowdfunding regulation in Europe, the contemporary regulatory experiences with the Banking Union's Single Rulebook point to positive effects of harmonised rules for all market participants, especially with regard to legal certainty and crossborder activities. The EU Crowdfunding regulation is therefore a step in the right direction with regard to enhancing investor protection and removing barriers for scaling of crowdfunding service providers and cross-border investments.

The EU Crowdfunding regulation should have a positive effect on investor protection in Croatia. At the same time, Croatia presents an interesting casestudy for several reasons. First, the Zagreb Stock Exchange has demonstrated its substantial proprietary knowledge through the combination of partnership with the Funderbeam platform while developing its own planform Progress for financing the SMEs. Second, the paper argues that there is a considerable pool of possible capital, in forms of households' savings, potentially available for investing. Third, non-sophisticated investors are already present at the capital markets' infrastructure, having registered securities accounts with the Central Depository and Clearing Company, while historical data shows that retail investors will not shy away from investing in good business projects in the capital market. Furthermore, the capital market's regulator HANFA has 
Regulating crowdfunding in the EU- same rules, same results? ...

undertaken plentiful regulatory and policy actions to remove barriers for investments and promote technology enabled financial market opportunities. Policy actions should therefore be focused on further improving digital financial literacy. Also, further improvements are needed in the areas of structural reforms toward a more supportive tax regime and resolute implementation of competitiveness strategies for entrepreneurship.

A recently published joint analysis of the Fintech innovation in Western Balkans by the World Bank and Cambridge Centre for Alternative Finance (2020, p. 17-26) identified barriers to finance, which present both challenges and opportunities for embracing Fintech and developing financial markets. They include: (i) low levels of account ownership and use of digital financial services, (ii) banks' risk aversion, (iii) high cash-use levels, (iv) reduced levels of trust in financial services, (v) comparatively low financial literacy rates, (vi) comparatively high cost of core financial services e.g. payments and credit and (vii) comparatively low levels of accessibility to financial and capital markets. Hence, there are five critical areas that countries in this region need to address in order to foster the development of FinTech startups within their own jurisdictions: access to data, use of digital government services, access to payment systems, access to capital, leasing and factoring. Cross-checking the above mentioned issues confirm that Croatia benefits from a comparatively more advanced financial ecosystem than the Western Balkan average. However, there is an urgent need to further improve digital financial literacy and implement necessary structural reforms.

\section{REFERENCES}

Amstad, M. (2019). Regulating Fintech: Objectives, Principles, and Practices, October 18, 2019, https://ssrn.com/abstract=3491982, Accessed February 2021.

Arner, D., Barberis, J., Buckley, R. (2016). The Evolution of FinTech: A New Post-Crisis Paradigm, 47 Georgetown Journal of International Law, 1271-1319

Bajakić, I. (2020). Transformation of financial regulatory governance through innovation facilitators - Case study of Innovation hub in Croatian capital markets, EU and comparative Law Issues and Challenges, Duić, D., Petrašević, T. (eds.) „EU 2020 - Lessons from the past and solutions for the future“", vol. 4, Josip Juraj Strossmayer University of Osijek, Faculty of Law Osijek, 917-946., http://doi.org/10.25234/eclic.

Bajakić, I. (2019). Capital Markets Union and European covered bonds initiative for upgrading capital markets in the New Member States, Book of Proceedings of $37^{\text {th }}$ International Scientific Conference on Economic and Social Development - Socio Economic Problems of Sustainable Development, Varaždin Development and Entrepreneurship Agency, Varaždin, Croatia, 67-75. 
Bank for International Settlements (2017). Distributed ledger technology in payment, clearing and settlement - An Analytical Framework, https://www.bis.org/cpmi/publ/d157.pdf, Accessed April 2019.

Batsaikhan, U., Demertzis, M. (2018). Financial literacy and inclusive growth in the European Union, Bruegel Policy Contribution Issue, No. 8, May 2018, https://www.bruegel.org/wp-content/uploads/2018/05/PC08 2018.pdf, Accessed February 2020.

Bower, J., Clayton, M., Christensen, M. (1995). Disruptive Technologies: Catching the Wave, Harvard Business Review, p. 43-53.

Business Insider (2016). Crowdfunding is growing up - SyndicateRoom just partnered with the London Stock Exchange, 14 ${ }^{\text {th }}$ March 2016, https://www.businessinsider.com/syndicateroom-get-intermediarystatus-with-london-stock-exchange-2016-3, Accessed April 2019.

Cambridge Centre for Alternative Finance (2020). The Global Alternative Finance Market Benchmarking Report Trends, Opportunities and Challenges for Lending, Equity, and Non-Investment Alternative Finance Models, https://www.jbs.cam.ac.uk/wpcontent/uploads/2020/08/2020-04-22-ccaf-global-alternative-financemarket-benchmarking-report.pdf, Accessed February 2021.

Cambridge Centre for Alternative Finance, Academy of Internet Finance (2018). Guide to promoting financial \& regulatory innovation Insights from the UK, University of Cambridge Judge Business School, Zheijang University, 2018, https://www.jbs.cam.ac.uk/fileadmin/user_upload/research/centres/alt ernative-finance/downloads/2018-06-ccaf-whitepaper-guide-topromoting-financial-regulation-innovation.pdf, Accessed April 2019.

Central Depository and Clearing Company (2021). Mjesečne statistike, [Monthly statistics], https://www.skdd.hr/ portal/f?p=100:601:7589940424248::NO:::, Accessed February 2021. ${ }^{2}$

CEPS (2011). MiFID 2.0 Casting New Light on Europe's Capital Markets, Report of the ECMI-CEPS Task Force on the MiFID Review, Centre for European Policy Studies, Brussels.

Christensen, C., Raynor, M., McDonald, R. (2015). What is Disruptive Innovation?, Harvard Business Review, https://hbr.org/2015/12/whatis-disruptive-innovation, Accessed April 2019.

Croatian National Bank (2021) Bilten 264, [Bulletin 264], https://www.hnb.hr/documents/20182/3754261/ hbilt264.pdf/680c1382-b679-e47f-2a17-4c9e52bb87b2, Accessed February 2021.

Ehrentraud, J., Ocampo, D.G., Vega, C.Q., (2020). Regulating fintech financing: digital banks and fintech platforms, Financial Stability Institute, FSI, Bank for International Settlements (BIS), Insights on

\footnotetext{
${ }^{2}$ The names of the documents in Croatian were translated into English by Ivana Bajakić and are in parentheses.
} 
Regulating crowdfunding in the EU- same rules, same results? ...

policy implementation, No 27, August 2020, https://www.bis.org/fsi/publ/insights27.pdf, Accessed February 2021.

European Central Bank (2009). Financial Integration in Europe, Frankfurt.

European Securities and Markets Authority (2017). Report - The Distributed Ledger Technology Applied to Securities Markets, ESMA50-1121423017-285,

https://www.esma.europa.eu/sites/default/files/library/dlt report _esma50-1121423017-285.pdf, Accessed April 2019.

European Commission (2020). Communication from the Commission to the European Parliament, the Council, the European Economic and Social Committee and the Committee of the Regions on a Digital Finance Strategy for the EU, Brussels, 24.9.2020 COM(2020) 591 final, https://eur-lex.europa.eu/legal-content/EN/TXT/

PDF/?uri=CELEX:52020DC0591\&from=EN, Accessed January 2021.

European Commission (2018a). FinTech Action plan: For a more competitive and innovative European financial sector, $\operatorname{COM(2018)~} 109$ final, 2018, https://eur-lex.europa.eu/resource.html?uri=cellar:6793c578-22e6-

11e8-ac73-01aa75ed71a1.0001.02/DOC_1\&format=PDF, Accessed March 2019.

European Commission (2018b). Commission staff working document impact assessment Accompanying the document Proposal for a Regulation of the European Parliament and of the Council on European Crowdfunding Service Providers (ECSP) for Business and Proposal for a Directive of the European Parliament and of the Council amending Directive 2014/65/EU on markets in financial instruments, Brussels, $\quad 8.3 .2018 \quad \operatorname{SWD}(2018) \quad 56 \quad$ https://ec.europa.eu/transparency/ regdoc/rep/10102/2018/EN/SWD2018-56-F1-EN-MAIN-PART-1.PDF, Accessed March 2019.

European Commission (2018c). Communication from the Commission to the European Parliament, the European Council, the Council, the European Central Bank, the European Economic and Social Committee and the Committee of the Regions Action Plan: Financing Sustainable Growth, Brussels, 8.3.2018 COM(2018) 97 final, https://eur-lex.europa.eu/legal-

content/EN/TXT/PDF/?uri=CELEX:52018DC0097\& from=EN, Accessed March 2019.

European Commission (2017). Communication from the Commission to the European Parliament, the Council, the European Economic and Social Committee and the Committee of the Regions on the Mid-Term Review of the Capital Markets Union Action Plan, Brussels, 8.6.2017 $\operatorname{COM}(2017) \quad 292$ final, https://eur-lex.europa.eu/legalcontent/EN/TXT/PDF/?uri=CELEX:52017DC0292\&from=EN,

Accessed March 2019.

European Commission (2015a). Green Paper: Building a Capital Markets Union, $\quad \mathrm{COM}(2015) \quad 63$ final, Brussels, 
http://ec.europa.eu/finance/consultations/2015/ capital-marketsunion/docs/green-paper_en.pdf, Accessed March 2018.

European Commission (2015b). Completing Europe's Economic and Monetary Union, 22 June 2015, https://ec.europa.eu/info/sites/info/files/5presidents-report en.pdf.

European Commission (2009). European Financial Integration Report 2008, Brussels.

European Commission (2005). FSAP Evaluation - Part I: Process and Implementation, Brussels.

European Commission (1999). Financial Services: Implementing Framework for Financial Markets: Action Plan, COM(1999)232, Brussels.

Europe Economics (2011). MiFID Review - Data Gathering and Cost-Benefit Analysis Phase One Final Report, $23^{\text {rd }}$ June 2011, London.

Ferran, E. (2004). Building an EU Securities Market, Cambridge University Press, UK.

Financial Stability Board, (2019). Fintech and market structure in financial services: Market development and potential financial stability implications, Financial Stability Board, https://www.fsb.org/wpcontent/uploads/P140219.pdf, Accessed March 2019.

Financial Stability Board (2017). Artificial intelligence and machine learning in financial services Market developments and financial stability implications, https://www.fsb.org/wp-content/uploads/P011117.pdf, Accessed March 2019.

HANFA (2021) Smjernice o provjeri i odobrenju prospekta te o izvř̌svanju ostalih obveza u vezi s javnom ponudom $i$ uvrštenjem vrijednosnih papira na uređeno tržište, [Guidelines on the verification and approval of the prospectus and on the execution of other obligations related to the public offering and listing of securities on the regulated market], https://hanfa.hr/media/5394/2-smjernice-za-prospekt.pdf, Accessed February 2021.

HANFA (2020). Smjernice o uređenim sustavima za prikupljanje kapitala, [Guidelines on regulated capital raising systems], https://www.hanfa.hr/media/4131/2-smjernice-o-ure\%C4\%91enimsustavima-za-prikupljanje-kapitala.pdf, Accessed January 2021.

Hardie, I, Howarth, D, Maxfield, S., Verdun, A (2013). Banks and the False Dichotomy in the Comparative Political Economy of Finance, 65(4) World Politics, 691-728.

Howarth, D., Quaglia, L. (2016). The Political Economy of European Banking Union, Oxford University Press.

Macchiavello, E. Siri, M. (2020). Sustainable finance and Fintech: can technology contribute to achieving environmental goals? A preliminary assessment of 'Green FinTech', EBI Working Paper Series, 13/08/2020, $\quad$ https://papers.ssrn.com/sol3/papers.cfm? abstract_id=3672989, Accessed February 2021.

McKinsey\&Company (2018). FinTech decoded-Capturing the opportunity in capital markets infrastructure, Global Banking Practice, March 2018, 
Regulating crowdfunding in the EU- same rules, same results? ...

https://www.mckinsey.com/ /media/McKinsey/Industries/Financial\% 20Services/Our\%20Insights/Fintech\%20decoded\%20The\%20capital $\% 20$ markets\%20infrastructure\%20opportunity/Fintech-decodedCapturing-the-opportunity-in-capital-markets-infrastructure-finalweb-version.ashx, Accessed March 2019.

Moloney, N. (2008). EC Securities Regulation, Oxford University Press, UK. Pintarić, J. (2020). Is the level of financial literacy improving in Croatia?, Croatian National Bank, https://www.hnb.hr/en/-/poboljsava-li-serazina-financijske-pismenosti-u-hrvatskoj, Accessed February 2021.

Restoy, F. (2021). Fintech regulation: how to achieve a level playing field, Financial Stability Institute Occasional Paper No 17, Bank for International Settlements

(BIS), https://www.bis.org/fsi/fsipapers17.pdf, Accessed February 2021.

Schueffel, P. (2016). Taming the Beast: A Scientific Definition of Fintech, October 31, 2016, Institute of Finance, School of Management Fribourg, Fribourg, Switzerland, SSRN, https://ssrn.com/abstract=3097312.

Schumpeter, J. (1942). Capitalism, Socialism and Democracy, First published in the USA 1942, This edition published in the Taylor \& Francis eLibrary, 2003. https://eet.pixelonline.org/files/etranslation/original/Schumpeter,\%20Capitalism,\%20 Socialism\%20and\%20Democracy.pdf, Accessed March 2019.

Zagreb Stock Exchange (2016). ZSE presents Funderbeam SEE, $7^{\text {th }}$ October 2016, http://zse.hr/default.aspx?id=74620, Accessed March 2019.

Ziegler, T., Shneor, R., Wenzlaff, K., Odorović, A., Johanson, D., Hao, R., Ryll, L. (2019). Shifting Paradigms - The $4^{\text {th }}$ European Alternative Finance Benchmarking Report, Cambridge Centre for Alternative Finance University of Cambridge Judge Business School, University of Agder School of Business Law, Invesco, CME Group Foundation, 2019, https://www.jbs.cam.ac.uk/wp-content/uploads/2020/08/201905-4th-european-alternative-finance-benchmarking-industry-reportshifting-paradigms.pdf, Accessed March 2019.

World Bank Group \& Cambridge Centre for Alternative Finance (2020). FinTech Innovation in the Western Balkans: Policy and Regulatory Implications \& Potential Interventions, https://www.jbs.cam.ac.uk/wpcontent/uploads/2020/08/2020-ccaf-fintech-innovation-western-

balkans.pdf, Accessed January 2021.

World Economic Forum \& Deloitte (2017). Beyond Fintech: A pragmatic assessment of disruptive potential in financial services, Part of the Future of Financial Services series, http://www3.weforum.org/docs/Beyond_Fintech_-

_A_Pragmatic_Assessment

of_Disruptive_Potential_in_Financial_Services.pdf, Accessed March 2019.

World Economic Forum\& Deloitte (2015). The Future of Financial Services How disruptive innovations are reshaping the way financial services 
are structured, provisioned and consumed, An industry project of the Financial Services Community, Final Report, http://www3.weforum.org/docs/WEF_The_future_of_financial_ services.pdf, Accessed March 2019.

\section{EU legislation}

Regulation (EU) 2020/1503 of the European Parliament and of the Council of 7 October 2020 on European crowdfunding service providers for business, and amending Regulation (EU) 2017/1129 and Directive (EU) 2019/1937, $\quad$ https://eur-lex.europa.eu/legalcontent/EN/TXT/PDF/?uri=CELEX:32020R1503\&from=EN, Accessed January 2021. 